\title{
Public Policies for Information Literacy in Portugal: an agenda in the making ${ }^{1}$
}

\author{
Tatiana Sanches \\ Institute of Education, Lisbon University, Lisbon, Portugal \\ tsanchesefpie.ulisboa.pt
}

\begin{abstract}
This theoretical study seeks to contribute to the reflection on public policies in the field of information literacy in Portugal. For this purpose, we look at the status quo of how information literacy has been addressed in Portugal, discussing the aspects concerning public policies, which include an interconnection between scientific knowledge and public action. So, the main objective is to describe Public Policies for Information Literacy in Portugal. Public policies usually result from a sustained effort which places a certain topic on the social agenda. This public action agenda seeks to draw the attention of society and obtain the support of influential groups or people and politics of different levels of the government. At the same time, we look at the way scientific knowledge gives rise to legislation, guidelines or policy recommendations. Finally, we propose a series of lines for reflection and debate on this matter.
\end{abstract}

Keywords: Public policies, scientific knowledge, information literacy, Portugal.

\section{Introduction: Information Literacy as a changing concept}

Information Literacy [IL] is the set of competencies, skills and capacities individuals apply in handling information, namely in searching, locating, selecting and using information for personal use, in an ethical and legal manner. It may be considered an essential capacity for the $21^{\text {st }}$ century. However, this notion is changing. The conceptual basis that is generally accepted is rooted in the definition established by ALA [1] and mentioned in the Presidential Committee on Information Literacy: Final Report, which explains that:

To be information literate, a person must be able to recognize when information is needed and have the ability to locate, evaluate, and use effectively the needed

${ }^{1}$ This is a pre-print version of a chapter published in Sanches, T. (2016) Public Policies for Information Literacy in Portugal: An Agenda in the Making. In Kurbanoglu, S., Špiranec, S., Grassian, E., Mizrachi, D., Catts, R. (Eds.), Information Literacy: Key to an Inclusive Society, pp. 563-575. Springer International Publishing. DOI:

10.1007/978-3-319-52162-6_56 Available online at: http://link.springer.com/chapter/10.1007/978-3-319-52162-6 56 
information. Producing such a citizenry will require that schools and colleges appreciate and integrate the concept of information literacy into their learning programs and that they play a leadership role in equipping individuals and institutions to take advantage of the opportunities inherent within the information society. Ultimately, information literate people are those who have learned how to learn.

This proposal presents a deep connection between acquired informational skills and capacities to learn throughout life. It is the key to understanding the importance of information literacy and the way it has been looked at for the past two decades. Nevertheless, the changes that have been taking place in parallel, namely on a social and technological level, raise other needs that are added to the concept of IL, as I shall explain further on.

Besides the above mentioned document, the American Library Association's Division, the Association of College \& Research Libraries, explains that a person who is empowered with information competencies [2, p.2-3] should be able to: determine the extent of information needed in an efficient and effective way, critically evaluate the information and its sources, incorporate information chosen according to his knowledge base, use the information effectively to fulfil a specific purpose, understand the economic, legal and social aspects involved in the use of information, and access and use the information ethically and legally.

These features were transformed into indicators which serve as a base to define five competency standards. In the same document, these were explored, examined and developed into performance indicators which give rise to measurable outcomes. The idea of establishing Information Literacy Competency Standards for Higher Education has to do with the need felt by the librarian and teacher community to compare, measure and evaluate performance levels achieved in university libraries as regards information literacy. This intention stems from the idea stated in the same document that the development of competencies in IL makes people more capable of dealing with information in different spheres of performance throughout life [2, p.4].

However, fifteen years after these reflections, these concepts, tools and guidelines have adapted to the new reality. Currently, there seems to be a convergence regarding the expansion of the conceptual framework of IL. Two significant milestones are those established by the Association of College \& Research Libraries (ACRL) and by UNESCO. Both organizations recently spoke out with respect to IL and its concept, its social influence and the way the educational and technological context affect learning and have impact on this concept. Both stressed the importance of mastering information to really be able to learn throughout life.

Following the above mentioned guidance document [2], the ACRL thought of reconceptualizing information literacy, giving a new background to the guidelines. Thus it is based on a new referential framework, which also relies on a new definition of IL $[3$, p.3]:

Information literacy is the set of integrated abilities encompassing the reflective discovery of information, the understanding of how information is produced and valued, and the use of information in creating new knowledge and participating ethically in communities of learning.

In this new document, Framework for Information Literacy for Higher Education, 
the main changes are in the structure of the document: instead of being designed as guidelines, it is now a theoretical and conceptual framework, focused on establishing coherent, but flexible lines of direction, thought to contain the key concepts to understand and apply information literacy, adapted to each reality. Based on six statements, it explains what seems to be a more global and simultaneously more specific frame for the application of information literacy. Paraphrasing the document, it is based on the ideas that authority is built and contextual, information is created as a process, information is valuable, searching must be understood as research, the academic community as dialogue, and searching as strategic exploration. This new conceptual frame was conceived as a theoretical construct from which we can understand IL and develop its application through new practices. These include the creation and use of resources, such as: curriculum guides, conceptual maps and evaluation tools, to add to the basic set of reflection materials that are provided. The framework rests on the central idea of meta-literacy (understanding the concept of literacy in depth), with special reference to the importance of meta-cognition and critical self-reflection as essential to make IL self-directed, in a constantly and rapidly changing ecosystem.

UNESCO prepared some official proposals that frame and explain the composed concept of Information and Media Literacy, having recently published a series of documents which relate the capacity to deal with information and with the media in a critical and informed manner: the guidance documents Media and information literacy: policy and strategy guidelines [4], and Global Media and Information Literacy Assessment Framework: Country Readiness and Competencies [5]. Underlying the decision to join these two concepts (information literacy and media literacy) is the need to equip citizens with the necessary competencies for them to seek and enjoy the benefits of universal human rights and fundamental freedoms, particularly freedom of speech and of access to information. Thus, this conceptual association highlights how faded the limits between these literacies are, stressing the need for information alphabetisation in a complex whole, proposing its integration and development in personal, educational, professional and social terms.

Some concepts, such as digital literacy, internet literacy, basic literacy or library literacy, circle around this larger concept like aggregate satellites. UNESCO's efforts to promote information and media literacy is not only visible in the above mentioned guidance documents, but also in the document Media and Information Literacy Curriculum for Teachers [6]. This document was developed with the intent to provide a practical tool to attain the objectives of the Grünwald Declaration [7], the Alexandria Declaration [8] and the Paris Agenda [9] - all of them related to Media and Information Literacy. It is a prospective document as it seeks to correspond to current convergence trends of radio, television, internet, newspapers, books, archives and physical and digital libraries in a single platform, showing they are all means to access information, regardless of the channel. Specifically designed for teachers, this document took into account the importance of integrating this learning in their formal education, thus enabling a process which aspires to reach and develop the capacities of millions of young people through teachers [6], and working as a catalyst for knowledge. After all, according to its authors, its main purpose is to face the challenge of evaluating the relevance and reliability of information without hindering citizens' full enjoyment of 
their rights to freedom of speech and to information. It is in this context that the need for media and information alphabetisation should be considered: it expands the movement for civic education that incorporates teachers as the main agents of change.

\section{Knowledge and policies: from theory to practice}

Currently the social context, especially as regards issues of citizenship, democracy and human rights, is on the agenda of researchers, sociologists, political scientists, educators and philosophers. The great issues of mankind seem to be affected by a change in communication: the simultaneity, virtual, free access and ubiquity of information are features that shape and define a new modernity. Bauman [10] spoke of a liquid modernity, which affects citizens on a general level, because it is contextual, and on a deeply individual level, influencing their ways of acting and intervening in this social system that is more connected than ever and yet more disconnected from everything and everyone. In a recent statement on the transformation of democracy in Europe, Habermas [11, p.2] reflected upon the ambivalent attitudes of citizens in Western democracies: while there is a significant decrease in voting, in collaborating in political parties and in other forms of political participation, which show a certain alienation and apathy towards the political sphere, at the same time there is a rapid growth of groups of citizens in active minorities, pressing for a more direct democracy. This is what the author calls a paradoxical simultaneity of contrasting reactions: growing indifference and intensified commitment - the so-called post-democratic syndrome. Also based on this author's work, Serrazina [12] refers to the current political system, describing it as based on the lack of participation. She points to a solution involving information and communication technologies, which are identified as the first necessary requirement for participation. Digital literacy is thus regarded as essential, representing the passage from the sphere of "being able to participate" to the sphere of "knowing how to participate". From this core point and to counter the tendency to move away from the public sphere, the author stresses the importance of communication, language and, inherently, the media, as well as the emergence of other dynamics of participation, related to informal environments, that should be valued and stimulated.

This short reflection is the backdrop for the following question: what is intended of public policies then - more commitment or more distance? More involvement of the State with citizens or more distancing, enhancing autonomy regarding decisions that affect their everyday lives?

With respect to public policies for education, these have sharply risen in the last few years in Portugal, with several educational fields (such as sex education in schools, autonomy in school management and external evaluation) having their activity regulated. Public policies are definitely on the agenda. But how can we understand and explain them? Barroso [13, p.4] suggests that, to better understand public policies, we must consider not only the State authorities' actions, but public action in general, and he states that, in politics, "problems do not exist outside of solutions". But what does this really mean? We must establish a correlation between problems, knowledge and 
policies. Understanding this correlation will allow us to better understand the role of policies and to explain subsequent interventions. Thus, understanding that scientific knowledge may be at the base of the problematization of situations that are the target of political intervention is the usual viewpoint of these situations. Another one is to understand that policies use knowledge to sustain themselves, presenting research facts and results as an argument for solving problems with which they seek to deal. In short, according to Barroso [13, p.7], often mobilised knowledge is of no use in finding solutions to problems, but it is to build problems adjusted to the available solutions. On the other hand, the author adds that more than direct action on policy decision-makers, knowledge (and research) have a direct influence on the process of public action, through multiple learning experiences (individual and organisational) that the different actors go through both by reflecting on their own practices and in more formal educational contexts.

This is the motto to explain the current state of public policies in Portugal, especially with respect to IL. We are at a time when studies and research that build knowledge around this concept are under way. However, in terms of higher education, there is not exactly a problematization of IL and, accordingly, public action is not mobilized to try and solve any situations regarding this. However, there are national documents that can be regarded as part of a political reference framework, for, as we shall see, they correspond to the assumptions defined by Barroso [13, p.3] and emerge in this explanation: "knowledge is transformed into policies and policies into knowledge, through an interactive and co-constitutive process, where problematization has a fundamental role".

Finally, public policies are usually the result of a sustained effort that places a certain topic on the social agenda. This public action agenda seeks to draw the attention of society and gather the support of influential groups or people and politicians from different levels of the government. Haras \& Brasley [14] studied the state of public policies in IL in the United States and found that they are still not a part of the public agenda. Instead, the topic of IL is claimed by a relatively select group of stakeholders, and it needs to gain acknowledgment and support from a vaster public. An objective sign of this reality, according to these authors, is the fact that it is not compulsory teaching in school, and therefore its implementation continues to be basically ineffective. In this article, IL is considered to be of justified public interest and therefore worthy of a policy. Thus, the authors suggest political options arise from identifying barriers, which will make it possible to provide recommendations for the development and dissemination of IL.

\section{$3 \quad$ A step further: legislation, guidelines or policy recommendations}

So, disseminating knowledge about IL has an important role. In a quick search in the largest portal aggregating Portuguese scientific production, the Portuguese Open Access Scientific Repository or RCAAP [15], carried out in April 2015, I obtained 
1,896 results regarding this term. In the last few years this topic has received more attention, as this sample shows regarding the evolution of the publications containing it: 2010 (176), 2011 (280), 2012 (375), 2013 (306), 2014 (245). However, by limiting our search to the inclusion of "information literacy" only in the title, which points to a greater relevance of the topic in that document, only 25 results are obtained. On the other hand, I carried out a search on the aggregating portals EBSCO HOST and B-on, as well as on the Web of Knowledge. It aimed to assess the current situation in terms of the available studies in this area, originating from Portugal. Eight results emerged, all of them referring to internationally published studies, with peer-review [16-22]. We recognise the need to promote knowledge in order to problematize a certain field, and we can thus raise the hypothesis that this is one of the reasons for the quasi-inexistence of public policies regarding information literacy: the lack of in-depth scientific knowledge mobilised around this field.

On the national level, we find a shortage of research, development and projection of knowledge. Nevertheless, some scattered projects and studies that have been carried out, namely in the Higher Education context, should be highlighted.

On the one hand, there are reports or case studies on the implementation of training programmes in information literacy [16]. On the other hand, there is more in-depth research which converges to projects and groups that publish results, such as Lopes \& Pinto [25] and Silva [26]. Also worthy of note are the PhD theses [27-29], and the ten Master's theses [30-39] that form the current body of scientific production specifically in information literacy, produced and made public to get academic degrees in recent years.

Externally, that is, supranationally, we have already seen that UNESCO recognises IL as a key subject for intervention. It states that in order to reach suitable levels of Media and Information Literacy for all, national policies are necessary. In this regard it has published a document that gathers strategic guidelines for Media and Information Literacy policies [5], set forth on a national level by each of the States. This resource is the first of its kind to approach the concept in a comprehensive way, joining Information Literacy and Media Literacy. These guidelines provide a harmonised approach that allows all stakeholders to promote more sustainable national strategies on Media and Information Literacy, describing the process and content to be considered.

With more specific reference to the policies in Media and Information Literacy, one important document - Media and Information Literacy Policies in Portugal (2013) was prepared by an inter-university research group (Lusófona, Nova and Minho Universities). In it, Costa, Jorge \& Pereira [40] carry out a transversal reading of the chronology of the most important publications resulting from public policies in these matters, serving as a guide for us to observe this reality, Actually this document was the result of a European project (2010-2014) whose line of action, "Transforming audiences / transforming societies", coordinated and promoted research efforts for fundamental transformations of European audiences as regards media in a changing environment, identifying their complex interrelations with the social, cultural and political fields in European societies. Once again we find the intrinsic connection between information literacy and media literacy.

As regards the official publication of documentation, there are several occasions on 
which we can understand how IL emerges as a related topic. The breakthrough document for educational policies in Portugal, Parecer do Conselho Nacional de Educação sobre Aprendizagem ao Longo da Vida [Opinion of the National Education Board on Lifelong Learning], mentions a set of assumptions to sustain an educational policy [41, p.11775]. It explains that the construction of a new model of learning, in which self-learning plays an important part, makes it necessary to reinforce partnerships and to pay special attention to recognition, validation and certification of learning. Achieving the important goals identified in this memorandum requires a prior general awareness of their importance and a marked will across society that naturally reflects the clear benefits each of us can reap from them. The very first chapter broadly addresses the problem of lifelong learning and refers to major topics: education in a context of change, the concept of lifelong learning, the right and duty of lifelong learning, basic competencies for lifelong learning, the (re)organisation of the learning system, partnerships for lifelong learning and learning in all domains of life, the need to regulate recognition, validation and certification of formal, non-formal and informal learning, and funding. With regard to the matter at hand, this document clearly mentions digital literacy, another macro-concept intrinsically connected to information literacy [41, p.11779]. In the second part, the National Education Board lays down 42 recommendations to put into practice the good implementation of the measures reflected upon, insisting on the appraisal of transversal learning.

On December 18, 2006, the Recommendation of the European Parliament and European Council on key competencies for lifelong learning [42] was published. It defines competencies as a combination of knowledge, skills and attitudes appropriate to the context. It states that key competences are those that support personal fulfilment, social inclusion, active citizenship and employment [42, p.394/13]. This recommendation seeks to respond to the previous diagnosis that a measurable improvement was needed in European average performance. These reference levels included reading literacy, early school leaving, completion of upper secondary education, and participation of adults in lifelong learning, all closely linked to the definition of these key competences.

In 2010, the National Education Board delivered Opinion no. 5/2010, Opinion on Educational Goals 2021 [43], published in the Portuguese Official Gazette on September 20, as the result of a supranational recommendation of the Organisation of Ibero-American States for Education, Science and Culture (OEI), of which Portugal is a member. This is a wide-ranging project focused on the definition of 11 educational goals, including monitoring indicators and expected levels of realisation. Though not explicit regarding information literacy, the document lays down comprehensive policy goals for education, again mentioning lifelong education.

In 2011, the National Education Board issued Recommendation no. 6/2011, Recommendation on Education for Media Literacy [44]. For me, this is the closest official document to a policy involving information literacy, quoting and using the previously mentioned UNESCO document for national policy, though more directed at media literacy.

This recommendation includes four major points: the first is introductory and states external and internal reasons. The second point concerns the concept of media literacy 
and refers to the scope, context and purpose of the recommendation. The third point consists of a brief chronology of the situation of media education and ICT in education in Portugal, mentioning key guidance documents and educational policies. Finally, the last point regards the current curricular situation and refers to the need to integrate these competencies in the school curriculum. This recommendation clearly shows an integration of the above mentioned concepts, even though there is a visible preference for the media field over the information field or the digital field.

In more extensive contexts, public libraries or school libraries have been more subject to the emanation of public policies with greater national impact, more wideranging and with greater social recognition, than university libraries. An example of this for public libraries is Nunes [45] who reflects on the role of these institutions in today's society, with special attention to reading promotion and literacies, regarded as social inclusion factors. This author explains the recent history of public libraries in Portugal and highlights the qualities and malfunctions that are visible in the National Network of Public Libraries, pointing to the development of public policies as a path for change. Parreira \& Calixto [46] discuss the legislation published about public libraries and conclude that the implementation of a law is necessary, though this is not the only way to create public policies.

As far as school libraries are concerned, Bastos [47] states that the 2007 Technological Plan for Education has played an important part in the educational context, encouraging schools and teachers to open their classes to new technologies and thus prepare students for the challenges of the knowledge society. This incentive emerges when the author mentions experiences of school libraries and information literacy, stating the impact of certain recent developments in the Portuguese school context, including the implementation of a self-evaluation model for school libraries.

Also worthy of note is the work of Pereira [48], whose research concentrates on digital literacy and the conceptual framework sustaining it, namely on the policies for technology in Portugal. The author points out some frailties in the implementation of the Technological Plan for Education, namely that with this policy government authorities sought to create the illusion of a reform of the school and of teaching, assuming that having technology would give the power for this to happen. Students equipped with new laptops are considered agents of change within the family. So there is a coherent thematic axis with the conceptual framework previously mentioned. It combines information literacy, digital literacy and media literacy as a multifaceted issue, which is the object of programmes and projects, legislation and regulation - in other words, it has been the target of public policies. Nonetheless, we can see that the definition of policies in information literacy is just beginning, so this exercise we carried out shows a very initial stage of the work which is yet to be done, especially concerning higher education.

\section{$5 \quad$ Final remarks: an agenda under construction for information literacy}


This study sought to find public policies on IL. But, as we saw previously, finding public policies set out in any matter of intervention and public action implies negotiating the interests of the political agenda that are in line with the emergence of a social problematization. This is only possible through knowledge and scientific research.

We found that the scientific knowledge circulating in Portugal is valuable but still at quite an initial stage and insufficient for this endeavour - to promote the creation of policies - because the problematization which emerges socially is still scarce. Nevertheless, we may conclude that external influences, together with social factors and interests from other adjacent quarters, have successfully managed to include topics regarding information literacy on the political agenda. Among these are lifelong learning, the importance of technologies in education, and digital and media literacy.

The OECD report Education Policy Outlook 2015: Making Reforms Happen, states that "the analysis of the chosen reforms shows that the most effective policies are those focused on students and on learning, that strengthen teachers' ability and involve all stakeholders" [49, p.1]. Therefore, we may say that social awareness is one clear path. Ponte [50, p.55] reminds us that when involving families in this process it is important to take into account certain critical factors. She gives the example of the implementation of public policies in Portugal, between 2005 and 2010, focused on the technological field. Seeking to facilitate the teachers' job and get parents interested and involved in school activities, these public policies considered the children as receivers of knowledge from their teachers, and "natural" promotors of their parents' info-inclusion. However, they forgot to consider conflicts and tensions that might arise due to different uses and generations. This is an example of lessons to be drawn from the implementation of public policies.

In 2014 another OECD project regarding policies was born - the project Skills Strategy. It includes a scheme for countries to develop a coordinated strategy of competencies, to be the baseline for making decisions about public policies. The Portuguese version is very recent [51]. Believing that better competencies create economic growth, the aim is to boost the conditions for equity in education, entrepreneurial competitiveness and job creation, building a society of active, committed and empowered citizens. The recommendations of this document point to the development of capacity and collaboration on a local level, creating evidence-based policies (which is underdeveloped in Portugal), expanding programme evaluation and regional evaluation, gathering data more systematically to anticipate competency needs, and reinforcing partnerships between stakeholders at different levels. These recommendations are quite flexible and therefore apply to policies of complementary spheres.

It is important to consider that the public agenda's space for negotiation as regards policies has first and foremost to do with the research done in university. It is essential to improve, deepen, systematise and present knowledge, making use of meta-literacy. From studies, projects and research we can bring the topic of information literacy to the public space, adjusting forms of intervention, shaping the role of the main social actors (essentially teachers and librarians), improving education and the curriculum. In this regard, the editors of the book Powerful Literacies [52, p.5] believe in the need for a systematic and sustained critique as a step towards knowledge, to change the literacy agenda from its current concerns and limitations to being more useful socially, with more interventional and creative approaches. On the national level, we find that most 
of the work has been carried out by the School Libraries Network Office. This government agency has already produced several documents, including "Aprender com a Biblioteca Escolar/Learning with the School Library" [53], a set of learning standards related to the work of school libraries in kindergarten and primary education. Here, reading literacy, media literacy and information literacy are discussed in detail, and strategies are presented to put into practice actions with students, in order to develop competences in these fields. Documents of this nature regarding higher education in Portugal could prove useful.

In conclusion, we may say that it is by mobilising knowledge that we can converge interests, efforts and finally actions to consolidate an educational framework where information literacy has a key place as a base for the creation and development of transversal competencies for all fields of lifelong learning.

\section{References}

1. ALA: American Library Association Presidential Committee on Information Literacy: Final Report 1989. Accessed April 2, 2015, http: / /www.ala.org/acrl/ publications/whitepapers/presidential

2. ALA: Information Literacy Competency Standards for Higher Education. Association of College and Research Libraries, American Library Association, Chicago (2000), http://www.ala.org/acrl/sites/ala.org.acrl/files/content/ standards/standards.pdf

3. ACRL, Association of College and Research Libraries, American Library Association, http: / / www.ala.org/acrl/

4. UNESCO: Global Media and Information Literacy Assessment Framework: Country Readiness and Competencies. UNESCO, Paris (2013), http://www. uis. unesco.org/Communication/Documents/mediaand-information-literacy-assessment-framework.pdf

5. UNESCO: Media and Information Literacy: Policy and Strategy Guidelines. UNESCO, Paris (2013), http://unesdoc.unesco.org/images/0022/002256/ $225606 \mathrm{e} \cdot \mathrm{pdf}$

6. Wilson, C. et al.: Media and Information Literacy Curriculum for Teachers. UNESCO, Paris (2011). Accessed April 10, http: //www. unesco.org/new/fileadmin/MULTIMEDIA/HQ/CI/CI/p $\mathrm{df} /$ media_and_information_literacy_curriculum_for_teachers en.pdf

7. ŪNESCO: Declaração de Grünwald sobre Educação para os Media. UNESCO, Grunwald (1982)

8. UNESCO: Declaração de Alexandria sobre Competência Informacional e Aprendizado ao Longo da Vida. The Alexandria Proclamation on Information Literacy and Lifelong Learning. IFLA UNESCO, Alexandria (2005). Accessed April 19, 2015, http: //www.ifla.org/files/assets/wsis/Documents/beaconinf soc-pt.pdf

9. UNESCO: Paris Agenda or 12 Recommendations for Media Education. UNESCO, Paris (2007), http: / /www.diplomatie.gouv.fr/fr/IMG/pdf / Parisagenda fin en.pdf

10. Bauman, Z.: Modernidade Líquida. Jorge Zahar, Rio de Janeiro (2001)

11. Habermas, J.: Democracy in Europe Today. In Conferência Internacional de Educação 2013: Os Livros e a Leitura: Desafios da Era Digital. Fundação Calouste Gulbenkian, Lisboa (2013). http: / / www . gulbenkian.pt/media/files/agenda /eventos13/28_10_13Comunicacao_Habermas_DemokratieInEurop 
a Lissabon.pdf

12. Serrazina, F.: Esfera Pública, Tecnologia e Reconfiguração da Identidade Individual, In Observatorio (OBS*), pp. 177-191, OberCom. 6, Lisboa (2012). Accessed May 15, 2015, http://obs.obercom.pt/index.php/obs/article/download/ $574 / 561$

13. Barroso, J.: Conhecimentos, Políticas e Práticas em Educação. In: Martins, A. M., Calderon, A. I., et al (eds.) Políticas e Gestão da Educação: Desafios em Tempos de Mudanças. Autores Associados, Campinas (2013)

14. Haras, C., Brasley, S. S.: Is Information Literacy a Public Concern?: a Practice in Search of a Policy. In: Library trends, 60, pp. 361-382, The Board of Trustees, University of Illinois, Illinois (2011), http: / / hdl . handle. net/2142/31875

15. RCAAP - Repositório Científico de Acesso Aberto de Portugal. Accessed April 12, 2015, http: / /www.rcaap.pt/

16. Sanches, T.: Reception and Application of Information Literacy Instruction in Portuguese Academic Libraries. In: Kurbanoğlu, S. (ed.) Information Literacy: Lifelong Learning and Digital Citizenship in the 21st Century: Second European Conference ECIL 2014, pp. 484-493 (Communications in Computer and Information Science, v. 492), Springer International Publishing, Dubrovnik, http://link.springer.com/chapter/10.1007/978-3-319-141367_51

17. Andrade, I., N. Camotim, M. A. Correia, R. Duarte, S. Lopes, A. Marques, A. Roxo, and S. Story. 2015. "O curso de Literacia da Informação da Escola Doutoral da NOVA."

18. Silva, A. M., V. F. Marcial, and F. Martins. 2014. "Lessons on Information Literacy Research: A Portuguese Experience." In Information Literacy: Lifelong Learning and Digital Citizenship in the 21 st Century, edited by S. Kurbanoglu, S. Spiranec, E. Grassian, D. Mizrachi and R. Catts, 180-188.

19. Lopes, Carlos Alberto. 2015. As competências da literacia da informação integradas nos curricula académicos.

20. Martins, J. T., and R. Canhoto. 2015. "The use of Narrative in Organisational Learning: Making Sense of Information Literacy Interventions." 14th European Conference on Research Methodology for Business and Management Studies, Univ Malta, Valletta, MALTA, Jun 11-12.

21. Martins, J. T., and R. M. Martins. 2012. "Portuguese School Libraries Evaluation Model: an Analysis of Primary Schools' results for the 'Reading and Literacy' Domain." Australian Library Journal 61 (4):265-280.

22. Terra, A. L. 2014. "Information Literacy Skills of Portuguese LIS Students: Some Topics on Evaluation of Resources Credibility." In Information Literacy: Lifelong Learning and Digital Citizenship in the 21st Century, edited by S. Kurbanoglu, S. Spiranec, E. Grassian, D. Mizrachi and R. Catts, 752-762.

23. Terra, A. L., and S. Sá. 2013. "Strategies to Assess Web Resources Credibility: Results of a Case Study in Primary and Secondary Schools from Portugal." In Worldwide Commonalities and Challenges in Information Literacy Research and Practice, edited by S. Kurbanoglu, E. Grassian, D. Mizrachi, R. Catts and S. Spiranec, 492-498.

24. Terra, A. L., and Salvina SÁ. 2007. "Uma análise de comportamento informacional: a utilização dos recursos da biblioteca escolar." Cadernos de Biblioteconomia, Arquivística e Documentação (2):82-92.

25. Lopes, C., Pinto, M.: IL-HUMASS - Instrumento de Avaliação de Competências em Literacia da Informação: um Estudo de Adaptação à População Portuguesa (Parte I). In: $10^{\circ}$ Congresso Nacional de Bibliotecários, Arquivistas e Documentalistas: Politicas de Informação na Sociedade em rede, BAD, Guimarães (2010), 2015, 
http: / / hdl.handle.net/10400.12/200

26. Silva, A. M.: Modelos e Modelizações em Ciência da Informação: o Modelo eLit.pt e a Investigação em Literacia Informacional. Prisma.Com, CETAC.Media 13, Aveiro (2010), http://revistas.ua.pt/index.php/ prismacom/article/view/785/710

27. Sanches, T.: O Contributo da Literacia de Informação para a Pedagogia Universitária: um Desafio para as Bibliotecas Académicas. Instituto de Educação, Universidade de Lisboa, Lisboa (2014), http://hdl.handle.net/10451/10773

28. Kanitar, F. P.: Avaliação de Competências Relacionadas com a Literacia de Informação: um Estudo no Contexto de Pós-Graduações em Educação. Doutoramento, Departamento de Educação, Departamento de Comunicação e Arte, Universidade de Aveiro, Aveiro (2014), http://hdl . handle.net/10773/12719

29. Braga, M. I. P.: A Literacia de Informação no Ensino Politécnico: Competências e Práticas numa Escola Superior. Doutoramento, Faculdade de Letras, Universidade do Porto, Porto (2014), http: //sigarra.up.pt/flup/pt/publs_pesquisa . show publ file?pct gdoc id=94534

30. Cordeiro, R. P. F.: Competências em Literacia da Informação: Estudo de Caso: Alunos de uma Escola E.B. 2,3. Mestrado, Departamento de Ciências da Educação e do Património, Universidade Portucalense, Porto (2011), http://repositorio.uportu.pt/jspui/bitstream/11328/86/2/T $\mathrm{MEB} \div 206 . \mathrm{pdf}$

31. Tomé, M. D. C.: A Biblioteca Escolar e o Desafio da Literacia da Informação: um Estudo Empírico no Distrito de Viseu. Mestrado, Departamento de Ciências da Educação, Universidade Aberta, Lisboa (2008), https : / / repositorioaberto .uab.pt/bitstream/10400.2/1222/1/Tese.pdf

32. Henriques, S. M. J. O.: Literacia da Informação: Projecto para Formação de Utilizadores na Biblioteca CDI da Faculdade de Medicina da Universidade de Lisboa. Mestrado, Faculdade de Letras, Universidade de Lisboa, Lisboa (2012), http: //hdl. handle.net/10451/6158

33. Bastos, V. M.: Literacia de Informação: Paradigma de Desenvolvimento de Competências de Informação na Formação Docente em Angola. Mestrado, Faculdade de Letras, Universidade de Lisboa, Lisboa (2010), http: //hdl. handle.net/10451/4246

34. Pedroso, F. M. F.: Literacia da Informação: um Projeto de Intervenção no Âmbito dos Comportamentos Informacionais dos Adolescentes. Mestrado, Departamento de Ciências da Educação e do Património, Universidade Portucalense, Porto (2012), http://hdl.handle.net/11328/929

35. Ferreira, S. R. R.: Literacia na Gravidez: Utilização da Internet como Fonte de Informação. Mestrado, Escola Superior de Enfermagem de Coimbra, Coimbra (2014), http://repositorio.esenfc.pt/rc/index.php? module=reposito $r y \& \operatorname{target}=\operatorname{details} \& i d s p=4530 \& l=1$

36. Mendinhos, I. M. G. B. S.: A Literacia da Informação em Escolas do Concelho de Sintra. Mestrado, Departamento de Educação e Ensino a Distância, Universidade Aberta, Lisboa (2009), 2015 https: / / repositorioaberto.uab.pt /bitstream/10400.2/1382/1/Binder3.pdf

37. Cravo, F. M. C.: As Bibliotecas Escolares e a Literacia da Informação: um Projeto numa Turma de $2^{\circ}$ Ciclo. Mestrado, Instituto de Educação, Universidade de Lisboa, Lisboa (2014), http: //hdl.handle.net/10451/16161

38. Augusto, M. d. J. G.: Literacia de Informação na Polícia de Segurança Pública. Mestrado, Instituto Superior de Contabilidade e Administração do Porto, Instituto Politécnico do Porto, Porto (2013), http://hdl . handle.net/10400.22/ 3214 
39. Dias, M. D. L. A. O Papel da Biblioteca Escolar no Desenvolvimento da Literacia de Informação e da Literacia Digital em Articulação com a Área de Projeto e Outros Contextos Letivos. Mestrado, Departamento de Educação à Distância, Universidade Aberta, Lisboa. (2011), http://hdl . handle.net/10400.2/2558

40. Costa, C., Jorge, A., Pereira, L.: Media and Information Literacy Policies in Portugal (2013). In: ANR TRANSLIT AND COST "TRANSFORMING AUDIENCES/TRANSFORMING SOCIETIES” " (2014) http: //ppemi.enscachan.fr/data/media/colloque140528/rappo rts/PORTUGAL_2014.pdf

41. CNE - Conselho Nacional de Educação. http : / /www . cnedu . pt/pt/

42. COMISSÃO EUROPEIA: Recomendação do Parlamento Europeu e do Conselho: de 18 de Dezembro de 2006: Sobre as Competências Essenciais para a Aprendizagem ao Longo da Vida. Jornal Oficial da União Europeia 962, 10-18 (2006), http: //www.ifdr.pt/ResourcesUser/OutrosInstrumentos Apoio/IC2007 2013/Rec 962 2006.pdf

43. CNE - Conselho Nacional de Educação: Parecer Sobre Metas Educativas 2021. In Diário da República, Parecer n. ${ }^{\circ}$ 5/2010 de 20/09, pp. 47612-47617. Ministério da Educação e Ciência, Lisboa (2010).

44. CNE - Conselho Nacional de Educação: Recomendação sobre Educação para a Literacia Mediática. In Diário da República, Recomendação n. ${ }^{\circ}$ 6/2011 de 30/12, pp. 50942-50947. Ministério da Educação e Ciência, Lisboa (2011).

45. Nunes, M. B.: Leitura, Literacias e Inclusão Social: Novos e Velhos Desafios para as Bibliotecas Públicas. In: Lopes, J. T. (ed.) Práticas de Dinamização da Leitura: Colectânea de Textos, pp. 48-59 (Públicos). Sete-Pés, Porto (2007)

46. Parreira, Z., Calixto, J. A.: A regulamentação legal das bibliotecas públicas. In $11^{\circ}$ Congresso Nacional de Bibliotecários, Arquivistas e Documentalistas: Integração, Acesso, Valor Social. BAD, Lisboa (2012), http: / / www.bad.pt/publicaco es/index.php/congressosbad/article/view/409/pdf

47. Bastos, G.: Collaboration or Parallel Worlds? Information Literacy Practices in Portuguese School Libraries. In: 17th European Conference on Reading: Literacy \& Diversity. Mons, Belgium (2011), https: / / repositorioaberto.uab.pt/ bitstream/10400.2/2142/1/Txt Bastos.pdf

48. Pereira, L. M. G.: Conceções de Literacia Digital nas Políticas Públicas - Estudo a Partir do Plano Tecnológico da Educação. Doutoramento, Instituto de Ciências Sociais, Universidade do Minho, Braga (2011), http: / / repositorium.sdum. uminho -pt/bitstream/1822/19825/1/LuC3\%ADs\%20Miguel\%20Gon\%C3\%A7 alves\%20Pereira.pdf

49. OECD: Education Policy Outlook 2015: Making Reforms Happen. OECD Publishing (2015). DOI:10.1787/9789264225442-en

50. Ponte, C.: Digitally empowered? Portuguese Children and the National Policies for Internet Inclusion. Estudos em Comunicação/ Communication Studies 11, 49-66 (2012), http://www.ec.ubi.pt/ec/11/pdf/EC11-2012Mai-03.pdf

51. OECD: OECD Skills Strategy Diagnostic Report: Portugal. OECD Publishing (2015) Accessed April 4, 2015, http: //skills.oecd.org/developskills/ documents/Portugal-Diagnostic-Report-web.pdf

52. Crowther, J., Hamilton, M., Tett, L.: Powerful Literacies. NIACE, London (2001)

53. Conde, E., Mendinhos, I., Correia, P., \& Martins, R. (coord.). Aprender com a biblioteca escolar: Referencial de aprendizagens associadas ao trabalho das bibliotecas escolares na educação pré-escolar e no ensino básico. Lisboa: Rede de Bibliotecas Escolares (2012). 